\title{
An Economics and Profitability of Predominant Farming Systems in Restored Tank Areas Undertaken under Mission Kakatiya
}

\author{
Salla Sowjanya* and R. Vijaya Kumari \\ Department of Agricultural Economics, \\ Jayashankar Telangana State Agricultural University, India \\ *Corresponding author
}

\section{A B S T R A C T}

\section{Keywords \\ Mission Kakatiya, farming systems, rehabilitation of tank}

\section{Article Info}

Accepted:

10 April 2020

Available Online:

10 May 2020
Tanks have been the main source of irrigation in many parts of India for centuries. In this connection, the Government has prioritized to take the restoration of minor irrigation tanks to restore them to store their original capacity and to effectively utilize of water allocated for Minor irrigation sector.The main aim of the Mission Kakatiya is improving the rural economy by encouraging the diversified enterprises. The present studies is on economics and profitability of predominant farming systems in areas with tank and without tank farms have been analyzed component wise and the pattern of total costs, gross returns, and returns per rupee spent on farming systems were worked out using simple budgeting technique. The number of farming systems followed by farmers in tank area before and after renovation was found to be 9 , while the same with respect to area without tank was 18. In areas with tank, the profitability high for Paddy-Paddy+Dairy followed by Paddy-Paddy+Dairy+Poultry and Paddy-Paddy+Dairy+Goat farming systems with returns per rupee spent was $1.72,1.71$ and 1.70 respectively. Whereas, in areas without tank the returns per rupee was 2.10, 1.79 and 1.77 for Paddy+ Lime, PaddyPaddy +Cotton and Paddy-Paddy +Cotton +Dairy respectively. It is confirmed that the paddy cultivation is carried out in both the seasons for majority of the farmers in areas with tank, as the water availability was increased after rehabilitation of tank under Mission Kakatiya programme. It could be concluded that the farming systems with diversified enterprises are highly profitable and with minimum risk.

\section{Introduction}

Water is one of the most valuable resources in the world and is vital to all known forms of life. Its availability determines where and how animals and plants exist on Earth. Water covers about $3 / 4$ of the earth's surface, but only about $2 \%$ is fresh water, and a larger portion of it is polar ice. 86\% of Asia's fresh water is used for agriculture, $8 \%$ for industry and $6 \%$ for domestic purposes. Our country uses $83 \%$ of fresh water for agriculture. (www.cpreec.org).

The per capita water availability in the country is reducing progressively due to increase in population. The average annual per capita availability of water in the country, 
taking into consideration the population of the country as per the 2001 census, was 1816 cubic meters which reduced to 1545 cubic meters as per the 2011 census. (Government of India, 2015).

Rainfed agriculture constitutes for 55 per cent of net sown area in the country. The annual average rainfall of the country varies from 400 to more than $2000 \mathrm{~mm}$ varying in both space and time. India uses only 10-20 percent of its annual rainfall. When it rains, only a fraction of the water percolates and reaches the ground water aquifers, while the major part of the rainfall drains out as run-off and goes unused into the ocean.

Further, lack of adequate storage facilities necessitate water being let into the sea to prevent breaching and flooding. The increasing numbers and depth of borewells and wells and their unrestricted use threaten India's ground water resources.

Tanks have been the main source of irrigation in many parts of India for centuries. Irrigation tanks are one of the oldest and most important common property water resources in the resource poor regions especially in South India. In this connection, understanding the importance of reclamation of tanks for growth in the state, the Government of Telangana State has taken up the programme of restoring the minor irrigation sources under the title "Mission Kakatiya" (Mana Ooru - Mana Cheruvu) in 2014. The mission aims at retrieving the lost glory of minor irrigation in the state with community participation for ensuring sustainable water security.

As per survey 46,531 number of M.I, Small tanks, Percolation tanks, Private Kuntas and Small tanks (built by Forest Department) were distinguished for restoration. The irrigation department has planned to restore all the 46,531 minor irrigation sources in the state in next five years in five phases, taking up $20 \%$ of the tanks each phase i.e., 9306 per year

(https://www.missionkakatiya.cgg.gov.in).

The main objective of this mission is to enhance the development of agriculture based income for small and marginal farmers by accelerating the development of minor irrigation infrastructure, strengthening community based irrigation management and adopting a comprehensive programme for restoration of tanks.

An Integrated farming system (IFS) is one which focuses on judicious combinations of any one or more of agriculture enterprises and effective recycling of wastes and crop residues for better management of available resources with small and marginal farmers to generate more income and employment for family labourers during off seasons. These enterprises not only supplement the income of the farmers but also help in increasing the family labour employment throughout the year.

In general, the small and marginal farmers practice subsistence farming where they need to produce a continuous, reliable and balanced supply of foods, as well as cash for basic needs and recurrent farm expenditure. Therefore, there is a need to develop suitable integrated farming systems for such farmers since monocropping / single crop production enterprise is subjected to high degree of risk and uncertainity because of seasonal, irregular and uncertain income and employment to the farmers.

The main aim of the Mission Kakatiya is improving the rural economy by encouraging the diversified enterprises, the present study on "An economics and profitability of predominant farming systems in restored tank areas undertaken under Mission Kakatiya" 
has been undertaken to identify the predominant integrated farming systems, to work out the economics and profitability of integrated farming systems.

\section{Materials and Methods}

Warangal and Nalgonda districts, where more number of tanks were selected for restoration under Mission Kakatiya in the year 2014-15 was purposively selected for the present study.

One tank in each district selected for the study. Using random sampling technique, a sample of 180 beneficiary households were selected from each restored tank in each district and 180 non-beneficiary households who are not covered under Mission Kakatiya were selected. Thus, a total of 720 households (360 from each district) were form the sample size for present study.

The primary data related to cost and returns, resource use etc collected from the selected sample farmers to fulfill the objective of the study using a pre tested schedule.

The present studies is on economics and profitability of predominant farming systems in areas with tank and without tank farms have been analysed component wise and the pattern of total costs, gross returns, and returns per rupee spent on farming systems were worked out using simple budgeting technique.

\section{Results and Discussion}

The number of farming systems followed by farmers in tank area before and after restoration of tank was found to be 9, while the same with respect to area without tank was 18. The various components included in a farming system by the sample farmers in the study area were paddy, cotton, red gram, green gram, ground nut, acid lime, maize, dairy, goat and poultry rearing activities.

The details of the different farming systems followed by sample farmers before and after restoration of tank are presented in Table 1 (Fig.1 and Fig. 2). Among 360 sample respondents maximum per cent of farmers were found practicing PaddyPaddy+Dairy(32.22 \%) fallowed by PaddyPaddy + Dairy + Poultry ( $23.61 \%$ ), PaddyPaddy (20.28 \%), Paddy + Dairy (9.72 \%), Paddy-Paddy+Poultry (6.67\%), PaddyPaddy+Dairy+Goat $\quad(3.06 \%), \quad$ PaddyPaddy+Goat+Poultry (2.22 \%), Paddy+Sheep+Poultry (1.67\%) and PaddyPaddy+Sheep $(0.56 \%)$ before restoration of tank.

When the same observed after restoration of tank (Table1 and Fig. 2), the highest proportion of sample farmers practicing a farming system consisting of PaddyPaddy+Dairy (36.39\%), followed by PaddyPaddy + Dairy + Poultry (27.22 \%), PaddyPaddy (13.06\% ) Paddy-Paddy+Poultry (7.78 $\%$ )and Paddy-Paddy+Dairy+Goat $(5.00 \%)$, other farming systems were in less percentage.

Among 360 sample farmers in study area without tank (Table 2 and Fig 3), maximum per cent of sample farmers were practicing Paddy+Cotton (18.61\%), followed by PaddyPaddy+Cotton (12.22\%), paddy - paddy + dairy system $(10.56 \%)$, paddy- paddy + red gram (10.00\%), paddy and dairy system (8.89\%) and Paddy+ Acid Lime (1.67\%), otherfarming systems were in less percentage. An economics and profitability of predominant farming systems observed after restoration of tank were presented in Table 3 . Out of total nine farming systems adopted by farmers as with tank only five farming systems were identified as predominant based on the percentage of adoption. 
Table.1 Different farming systems adopted before and after restoration of tank by sample farmers

\begin{tabular}{|l|c|c|c|c|}
\hline Farming system & \multicolumn{3}{|c|}{ Before restoration of tank } & \multicolumn{2}{|c|}{ After restoration of tank } \\
\cline { 1 - 5 } & $\begin{array}{c}\text { Number } \\
\text { of } \\
\text { farmers }\end{array}$ & $\begin{array}{c}\text { Percent to } \\
\text { total }\end{array}$ & $\begin{array}{c}\text { Number of } \\
\text { farmers }\end{array}$ & $\begin{array}{c}\text { Percent to } \\
\text { total }\end{array}$ \\
\hline P-P & 73 & 20.28 & 47 & 13.06 \\
\hline P-P+D & 116 & 32.22 & 131 & 36.39 \\
\hline P-P+D+G & 11 & 3.06 & 18 & 5.00 \\
\hline P-P+G+Po & 8 & 2.22 & 15 & 4.17 \\
\hline P-P+D +Po & 85 & 23.61 & 98 & 27.22 \\
\hline P-P+S & 2 & 0.56 & 2 & 0.56 \\
\hline P-P+Po & 24 & 6.67 & 28 & 7.78 \\
\hline P+D & 35 & 9.72 & 15 & 4.17 \\
\hline P+S+Po & 6 & 1.67 & 6 & 1.67 \\
\hline Total & 360 & 100 & 360 & 100.00 \\
\hline
\end{tabular}

P-Paddy, D-Dairy, S-Sheep, Po-Poultry, G-Goat

Table.2 Different farming systems adopted by sample farmers in areas without tank

\begin{tabular}{|l|c|c|}
\hline Farming system & Number of farmers & Percent to total \\
\hline P-P & 14 & 3.89 \\
\hline P-P+D & 38 & 10.56 \\
\hline P-P+D+Po & 17 & 4.72 \\
\hline P-P+D+S & 10 & 2.78 \\
\hline P+D+Po+G & 3 & 0.83 \\
\hline P-P+RG & 36 & 10.00 \\
\hline P-P+RG+D & 23 & 6.39 \\
\hline P-P+RG+D+Po & 7 & 1.94 \\
\hline P-P+C & 44 & 12.22 \\
\hline P+C & 67 & 18.61 \\
\hline P-P+C+D & 26 & 7.22 \\
\hline P+L & 6 & 1.67 \\
\hline P+L+D & 4 & 1.11 \\
\hline P+GN+D & 7 & 1.94 \\
\hline P-P+GG & 9 & 2.50 \\
\hline P-P+GG+D & 13 & 3.61 \\
\hline P+M+D & 4 & 1.11 \\
\hline P+D & 32 & 8.89 \\
\hline Total & 360 & 100.00 \\
\hline
\end{tabular}

P-Paddy, D-Dairy, S-Sheep, Po-Poultry, G-Goat, RG- Red gram, GG- Green gram, GN- Ground nut, L- Acid Lime, M-Maize, C- Cotton 
Table.3 Component wise per farm cost and returns of predominant farming systems adopted by farmers with tank

\begin{tabular}{|l|c|c|c|c|c|}
\hline Component & $\begin{array}{c}\text { Area } \\
\text { (ha) /no. }\end{array}$ & $\begin{array}{c}\text { Total cost } \\
\text { (Rs.) }\end{array}$ & $\begin{array}{c}\text { Gross return } \\
\text { Rs. }\end{array}$ & $\begin{array}{c}\text { Net return } \\
\text { (Rs.) }\end{array}$ & $\begin{array}{c}\text { Return } \\
\text { per rupee } \\
\text { spent }\end{array}$ \\
\hline Paddy (kharif) & 0.52 & 28690 & 51369 & 22679 & 1.79 \\
\hline Paddy (rabi) & 0.52 & 29992.2 & 47634.9 & 17642.7 & 1.59 \\
\hline Dairy & 2.7 & 35100 & 62641 & 27541 & 1.78 \\
\hline Total & & 93782.2 & 161645 & 67862.7 & 1.72 \\
\hline & & FS II- (P-P+D+Po) & & \\
\hline Paddy (kharif) & 0.62 & 33110 & 57963 & 24853 & 1.75 \\
\hline Paddy (rabi) & 0.62 & 34159.4 & 55964.6 & 21805.2 & 1.64 \\
\hline Dairy & 3 & 38340 & 65962 & 27622 & 1.72 \\
\hline Poultry & 5.3 & 1213.7 & 2356 & 1142.3 & 1.94 \\
\hline Total & & 106823 & 182246 & 75422.5 & 1.71 \\
\hline & & \multicolumn{2}{|c|}{ FS III- (P-P) } & & \\
\hline Paddy (kharif) & 0.36 & 19563 & 31875 & 12312 & 1.63 \\
\hline Paddy (rabi) & 0.36 & 22931.5 & 35589 & 12657.5 & 1.55 \\
\hline Total & & 42494.5 & 67464 & 24969.5 & 1.59 \\
\hline & & FS IV- (P-P+Po) & & 1.5 \\
\hline Paddy (kharif) & 0.32 & 17900 & 30126 & 12226 & 1.68 \\
\hline Paddy (rabi) & 0.32 & 19069.6 & 29022.4 & 9952.85 & 1.52 \\
\hline Poultry & 7.5 & 2215 & 4175 & 1960 & 1.88 \\
\hline Total & & 39184.6 & 63323.4 & 24138.9 & 1.62 \\
\hline & & FS V- (P-P+D+G) & & 1.5 \\
\hline Paddy (kharif) & 0.43 & 21658 & 34656.3 & 12998.3 & 1.60 \\
\hline Paddy (rabi) & 0.43 & 23456 & 35487 & 12031 & 1.51 \\
\hline Dairy & 1.6 & 14213 & 25654 & 11441 & 1.80 \\
\hline Goat & 8.9 & 22525.8 & 43241 & 20715.2 & 1.92 \\
\hline Total & & 81852.8 & 139038 & 57185.5 & 1.70 \\
\hline
\end{tabular}


Table.4 Component wise per farm cost and returns of predominant farming systems adopted by farmers without tank

\begin{tabular}{|c|c|c|c|c|c|}
\hline Component & $\begin{array}{c}\text { Area } \\
\text { (ha) /no. }\end{array}$ & $\begin{array}{l}\text { Total cost } \\
\text { (Rs.) }\end{array}$ & $\begin{array}{l}\text { Gross } \\
\text { return } \\
\text { (Rs.) }\end{array}$ & $\begin{array}{l}\text { Net return } \\
\text { (Rs.) }\end{array}$ & $\begin{array}{l}\text { Return } \\
\text { per rupee } \\
\text { spent }\end{array}$ \\
\hline \multicolumn{6}{|c|}{ FS I- (P-P+D) } \\
\hline Paddy (kharif) & 1.4 & 68300 & 110262 & 41962 & 1.61 \\
\hline Paddy (rabi) & 1.4 & 70265 & 108568 & 38303 & 1.55 \\
\hline Dairy & 2.1 & 26457 & 46845 & 20388 & 1.77 \\
\hline Total & & 165022 & 265675 & 100653 & 1.61 \\
\hline \multicolumn{6}{|c|}{ FS II- (P-P+RG) } \\
\hline Paddy (kharif) & 0.75 & 41946 & 68936 & 26990 & 1.64 \\
\hline Paddy (rabi) & 0.75 & 40136 & 65256 & 25120 & 1.63 \\
\hline Red gram & 0.6 & 26471 & 45895 & 19424 & 1.73 \\
\hline Total & & 108553 & 180087 & 71534 & 1.66 \\
\hline \multicolumn{6}{|c|}{ FS III- (P-P+C) } \\
\hline Paddy (kharif) & 0.36 & 18924 & 31950 & 13026 & 1.69 \\
\hline Paddy (rabi) & 0.36 & 20654 & 32412 & 11758 & 1.57 \\
\hline Cotton & 1.61 & 89129 & 166524 & 77395 & 1.87 \\
\hline Total & & 128707 & 230886 & 102179 & 1.79 \\
\hline \multicolumn{6}{|c|}{ FS IV- $(\mathbf{P}+\mathbf{C})$} \\
\hline Paddy & 0.24 & 13425 & 22145 & 8720 & 1.65 \\
\hline Cotton & 1.2 & 71923 & 126861 & 54938 & 1.76 \\
\hline Total & & 85348 & 149006 & 63658 & 1.75 \\
\hline \multicolumn{6}{|c|}{ FS V- $(P+D)$} \\
\hline Paddy & 0.37 & 18764 & 32421 & 13657 & 1.73 \\
\hline Dairy & 2 & 24558 & 44523 & 19965 & 1.81 \\
\hline Total & & 43322 & 76944 & 33622 & 1.78 \\
\hline \multicolumn{6}{|c|}{ FS VI- (P+L) } \\
\hline Paddy & 0.29 & 15587.5 & 27531.9 & 11944.4 & 1.77 \\
\hline Acid lime & 2 & 252642 & 536785 & 284143 & 2.12 \\
\hline Total & & 268230 & 564317 & 296087 & 2.10 \\
\hline
\end{tabular}




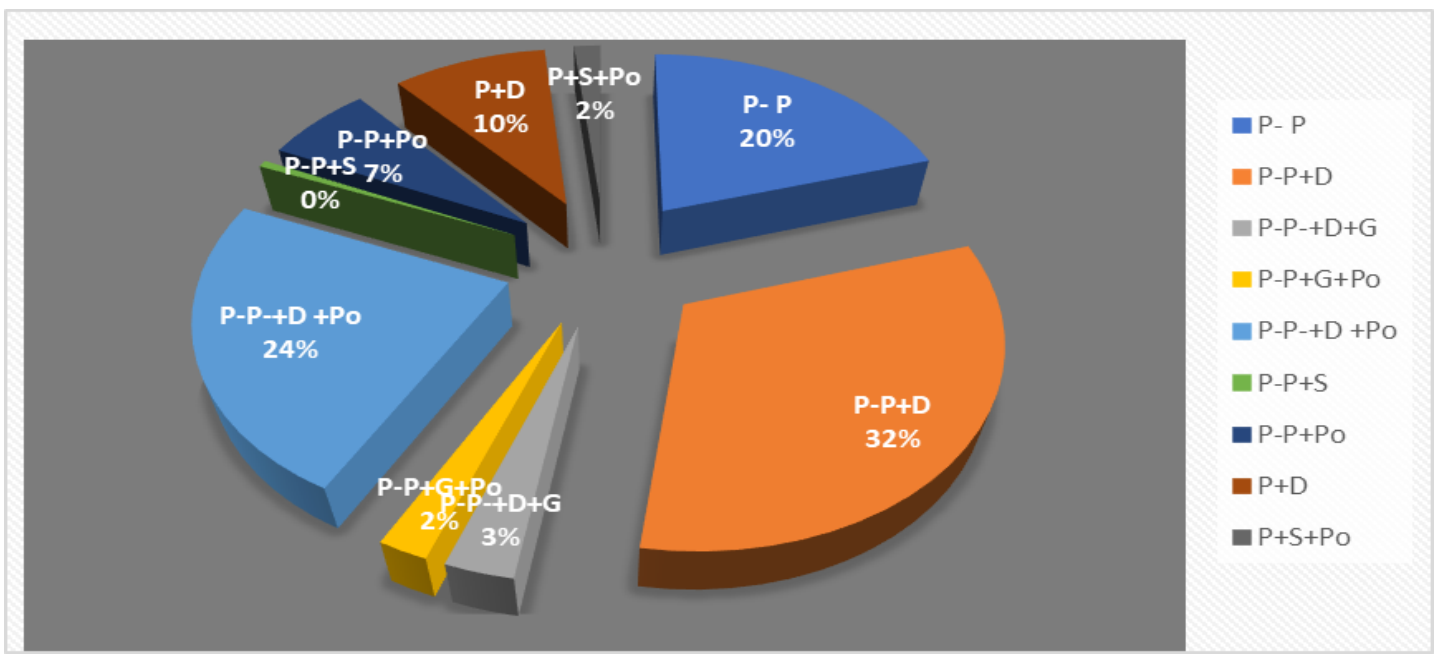

Figure.1 Different farming systems adopted before restoration of tank by sample farmers

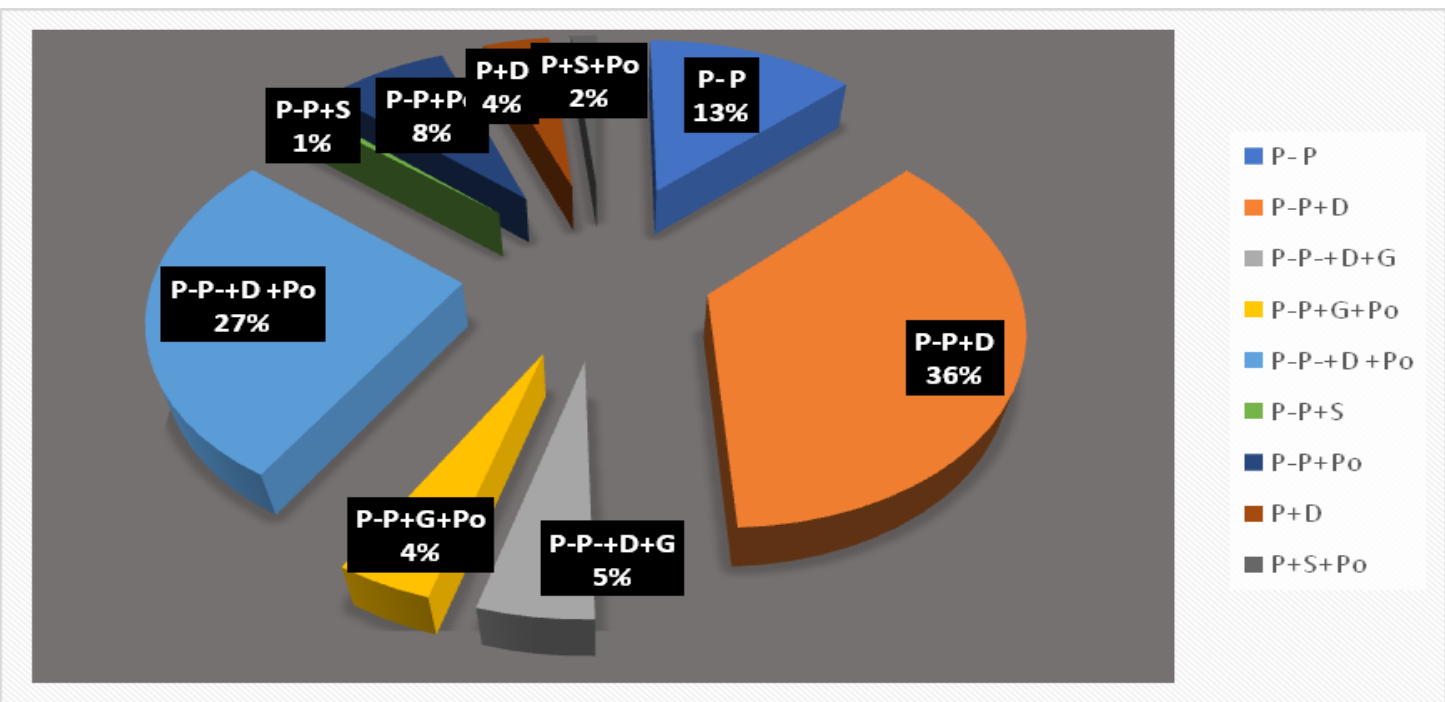

Figure.2 Different farming systems adopted after restoration of tank by sample farmers

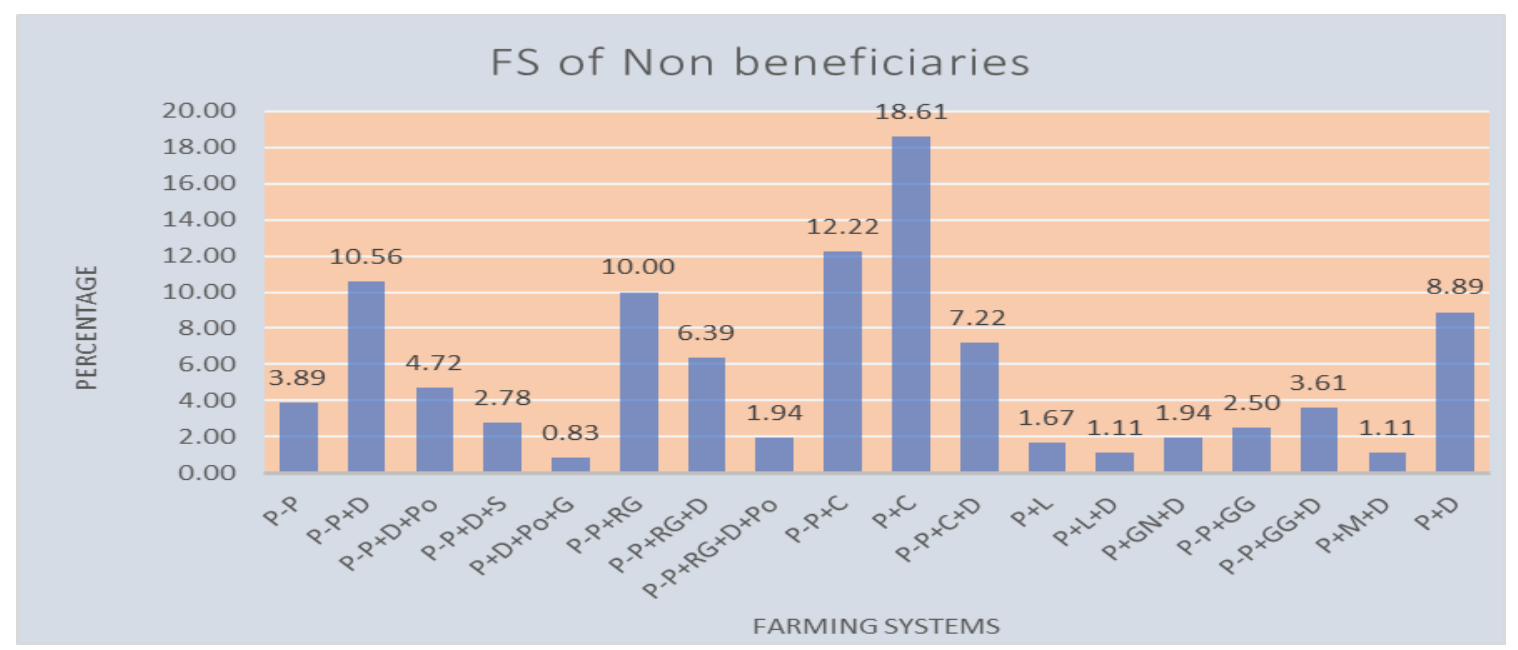

Figure.3 Different farming systems adopted by sample farmers in areas without tank 
Total cost for FS - I, FS - II, FS - III, FS - IV and FS - V were Rs. 93782.2, Rs. 106823, Rs. 42494.5, Rs. 39184.6 and Rs. 81852.8 respectively. Similarly, gross returns from FS - I, FS - II, FS - III, FS - IV and FS - V were Rs. 161645, Rs. 182246, Rs. 67464, Rs. 63323.4 and Rs. 139038. The return per rupee spent for the total system for FS - I, FS - II, FS - III, FS - IV and FS - V was 1.72, 1.71, $1.59,1.62$ and 1.70 respectively.

Devasenapathy et al., (1995) also reported that the integrated farming with GroundnutBlackgram-Maize and Groundnut-GingellyRagi with integration of other enterprises such as dairy, poultry and rabbit rearing resulted in higher net income and benefit-cost ratio. An economics and profitability of six major farming systems in without tank areas were presented in Table 4. Total cost for FS - I, FS - II, FS - III, FS - IV, FS - V and FS - VI were Rs.165022, Rs. 108553, Rs. 128707, Rs. 85348, 43322 and Rs. 268230 respectively.

Similarly, gross returns from FS - I, FS - II, FS - III, FS - IV FS - V and FS - VI were Rs. 265675, Rs. 180087, Rs. 230886, Rs. 149006, 76944 and Rs. 564317 respectively. The return per rupee spent for the total system for FS - I, FS - II, FS - III, FS - IV, FS - V and FS - VI was 1.61, 1.66, 1.79, 1.75, 1.78 and 2.10 respectively. The results are similar to the results of Rangaswamy (1999).

The socio-economic characters of the sample farmers were, majority number of respondents belonged to middle age (36-55 years) in both tank and non-tank areas. The educational level of sample farmers in the case of tank area was higher than the non-tank area. Majority of the farmers selected under tanks were marginal followed by small farmers. The farmers in tank area had high socio-political participation, as compared to sample farmers in non-tank area. The average farm size of the respondents with tank was 0.44 ha and without tank was 1.36 ha.
It was noted from the Table 1 and 2 , that paddy was one of the major agriculture components in all the farming systems in the selected area. Majority farmers in the study area with tank cultivated paddy in both kharif and rabi seasons due to availability of the water. The irrigation facilities are more for tank beneficiary farmers compared to farmers in area without tank. The area cultivated under paddy increased after restoration of the tank under Mission Kakatiya when compared to before restoration of the tank. The main aim of the Mission Kakatiya is improving the rural economy by encouraging the diversified enterprises. Areas without tank in Nalgonda district, horticultural crop (Acid lime) component was also appeared in good number of farming systems.

It is confirmed from the Table 3 and 4 , that the paddy cultivation is carried out in both the seasons by majority farmers in tank area, as the water availability was increased after restoration of tank under Mission Kakatiya programme. From the presented results it could be concluded that the farming systems with diversified enterprises are highly profitable with minimum risk.

\section{Policy implications}

The state agricultural department should take initiatives for further promotion diversification of farming systems through their wide spread extension activities.

Government should encourage the community-based tank management system to increase the availability of water for diversified crops and livestock.

\section{Acknowledgment}

I gracefully record my profound sense of gratitude and regards to the chairman and major advisor, DR. R. Vijaya Kumari, Associate Professor in the Department of 
Agricultural Economics and minor advisors Dr. T. Lavanya, AssociateProfessor in the Department of Agricultural Economics, Dr. Seema, Associate Dean, College of Agriculture, Rajendranagar, PJTSAU and Dr. D. Srinivasa Chary, Associate Professor, Statistics and Mathematics, PJTSAU and Dr. K. Suhasini (Univ. Head) Professor\& Head, Department of Agricultural Economics, College of Agriculture, PJTSAU for the unbounded affection, cheerful assistance and encouragement during my course of study.I humbly thank the authorities of Professor Jayashankar Telangana State Agricultural University and Government of Telangana for the financial help in the formofstipend duringmystudyperiod.

\section{References}

Basavaraj, H. 1999. Economic assessment of integrated farming systems. In : Lecture Notes of Summer Short Course on Farming Systems for Sustainable Production. University of Agricultural Sciences, Dharwad., 24th May to 2nd June 1999. 270-274.

Devasenapathy, P., Mytswamy, V., Christopher Louduraj, A and Rabindran, R. 1995. Integrated farming systems for sustained productivity. Madras. Agricultural Journal. 82: 306-307.

Ganesan, S., Chinnaswami, K. N., Chandraskaran, B., Budhar, M. N. and Prince Jayaseelan, M. J. 1991. Duck-cum-fish culture in farming systems in Cauvery delta region of Tamil Nadu: The Aduthurai experiment. Indian Journal of Agricultural Economics. 46 (2): 180-185. https://www.missionkakatiya.cgg.gov.in

Kandasamy, O. S. 1998. An economic analysis of IFS in Dharmapuri District of Tamil Nadu. Farming Systems. 14 (12): 29-33.

Palanisami, K. 2006. Sustainable management of tank irrigation systems in India.Water Technology Centre, Tamil Nadu Agricultural University, India.

Rangaswamy, A. 1999. Integrated farming systems for sustainable crop production. Lecture notes of summer short course on farming systems for sustainable production. University of Agricultural Sciences, Dharwad. 1-20.

Saikumar, B. C. 2005. Farming systems in the tank commands in north eastern Karnataka - an economic analysis of JalaSamvardhane Yojana Sangha managed tanks. M.Sc Thesis. University of Agricultural Sciences GKVK, Banglore.

Sharma, L. R., Bhhati, J. P. and Ranveer, S. 1991. Emerging farming systems in Himachal Pradesh-Key issues in sustainability. Indian Journal of Agricultural Economics. 46(3):422427.

Singh, S. N., Saxena, K. K., Singh, K. P., Harish Kumar and Kadian, V. S., 1997, Consistency in income and employment generation in various farming generation in various farming systems. Mannual of Agricultural Research. 18(3): 340-363.

Swaminathan, M. S. 1996. Integrated intensive farming systems. Indian Farming. 46(7): 5960.

Tanver Ahmed. 2006. An economic analysis of paddy based farming systems in Southern Karnataka - A case study of Mandya district. M.Sc Thesis. University of Agricultural Sciences, Dharwad.

www.cpreec.org

\section{How to cite this article:}

Salla Sowjanya and Vijaya Kumari. R. 2020. An Economics and Profitability of Predominant Farming Systems in Restored Tank Areas Undertaken under Mission Kakatiya. Int.J.Curr.Microbiol.App.Sci. 9(05): 1290-1298. doi: https://doi.org/10.20546/ijcmas.2020.905.143 